\title{
Inverse problem of life cycle assessment (LCA): its application in designing for environment (DfE)
}

Magdalena Rybaczewska-Blażejowska, Ph.D.

Kielce University of Technology Department of Production Engineering

Aneta Masternak-Janus, Ph.D. Kielce University of Technology Department of Production Engineering

Wacław Gierulski, Professor Kielce University of Technology Department of Production Engineering

\section{Introduction}

Design for environment (DfE) is a very broad concept, having multiple definitions that are concurrently used in the literature. According to Fiksel and Wapman (1994, pp. 75-80) DfE means 'systematic consideration during new product and process development of design issues associated with environmental safety and health over the full product life-cycle'. Telenko et al. (2008, pp. 1-13) specified the principles of design for environment, including sustainable use of resources, ensuring healthy inputs and outputs, minimal use of resources in the production and transportation phases, minimal use of resources during the use phase, appropriate durability of the product and its components, and finally enabling disassembly, separation and purification. The fulfilment of these guidelines, and thus of DfE principles, covers a breadth of environmental aspects, including adequate material selection, the reduction of energy consumption, waste reuse and recycling and contamination avoidance as well as a number of 'design for' techniques, such as, design for disassembly (DfD), design 
for recyclability (DfR) or design for remanufacture (DfRem) (Arnette et al. 2014, pp. 374-390).

Nowadays, the ideas of DfE have been incorporated into new concepts like green design (green products) and eco-design (eco-products) that focus on the integration of environmental considerations into product development with the aim of improving the environmental performance of the product throughout its life cycle (Karlsson, Luttropp 2006, pp. 1291-1298; Ecodesign Directive 2009; Fargnoli 2009, pp. 33-39; Herva et al. 2012, pp. 4427-4431). To make it possible, designers should have access to relevant eco-design tools during the product development process.

There are multiple qualitative, semi-quantitative and quantitative tools for evaluating the environmental performance of products (Bovea, Perez-Belis 2012, pp. 61-71). The qualitative and semi-quantitative ones, e.g. checklists (including the eco-design checklist method), MET-matrix, ten golden rules or the product investigation learning and optimization tool (PILOT), are fairly quick, simple to use and can be applied in the early product development stage. The quantitative methods, e.g. environmental indicators or life cycle assessment (LCA), are useful when a detailed environmental profile of a product is researched, but they require a lot of data about the product before it is designed, and hence they tend to be applied in a fairly late stage of the design process, when only minor changes can be made. Considering the above, three key factors make the eco-design tools effective: (1) early integration of environmental aspects into the product design and development process; (2) the life cycle approach; and (3) a multi-criteria approach (Birch et al. 2012, pp. 50-58).

LCA is one of the major tools to assist in ensuring proper sustainability through assessing the environmental impacts of a product (Chang et al. 2014, pp. 48-60). Moreover, it is one of the most successful DfE tools, since - as it was emphasized above - its simplified version can be used in the early stages of the design process, is practiced worldwide and is formalised into ISO 14040:2006 and ISO 14044:2006 norms (Millet et al. 2007, pp. 335-346; ISO 2006a, b). Telenko et al. (2008, pp. 1-13) argue, however, that full LCA is usually performed when the design is near completion and thus acts retroactively, resulting in reality in only few design changes. Nevertheless, it is also an indispensable tool to draw up the most detailed cartography of the environmental effects and impacts associated with a product (existing and not very complex) (Millet et al. 2007, pp. 335-346). LCA has been applied in eco-design process in various industrial sectors, such as the lighting industry (Casamayor, Su 2012, pp. 32-42), food industry (Zufia, Arana 2008, pp. 1912-1921), textile industry (Van der Velden et al. 2015, pp. 313- 
324), auto industry (Luza et al. 2010, pp. 1135-1144), paper industry (MasternakJanus, Rybaczewska-Błażejowska 2015, pp. 47-54) or finally the transport sector (Andriankaja et al. 2015, pp. 165-176). The obtained information helps designers to optimize the life cycle of a product, understood as the usage of the best available solutions consistent with the environmental principles of sustainable development. Solving the inverse problem of LCA may particularly support decision-making processes in DfE, since it facilitates finding an optimal solution from the environmental point of view, without the necessity of reaching it by trial and error.

The aim of the presented research is to propose and develop the inverse problem of LCA technique in DfE. The inverse problem theory and methods arise in engineering, economics and many branches of science, such as mathematics, physics, chemistry, life sciences and computer science (Wang et al. 2012). There are many fundamental publications explaining the theory of inverse problems (Hensel 1991; Engl et al. 2000). Over the last few decades, a number of the publications have examined, developed and applied this theory in both science and industry (Kunze et al. 2014; Argoul 2012, pp. 1-13). However, the application of the inverse problem of LCA in DfE represents a new approach and it is one of the first attempts of this type (Kaczmarska, Gierulski 2014, pp. 48-55). The formulation of the inverse problem of LCA with linearization and basic information on the coefficients are presented in the following section of this paper. The next section outlines the case study of a coffee machine and computational optimization task, which aims to minimize the established measure of the difference between the expected and the actual environmental impacts. The final section of the article includes conclusions and recommendations.

\section{Methodology}

LCA is a technique that enables the identification and evaluation of environmental impacts related to a product system throughout all stages of its life cycle (ISO 2006a, b). Consequently, a detailed LCA analysis covers the following life cycle stages: the extraction of resources, the production of materials, product parts and the product itself, and the use of the product as well as its management after it is discarded, by either reuse, recycling or final disposal (Tukker 2002). LCA is, hence, understood as a 'cradle to grave' or 'cradle to cradle' analysis. The term 'product' has the broadest sense, since it includes physical goods as well as services and technological processes (Horne et al. 2009). Regulated by the 
ISO 14040 series of standards, LCA consists of four basic phases: goal and scope definition, life cycle inventory (LCI), life cycle impact assessment (LCIA) and interpretation (ISO 2006a, b).

Given the complexity of LCA research, there is a wide range of tools, so-called specialized computer programs, supporting such analyses. They enable, upon input data, building an environmental profile (life cycle impact assessment, LCIA) of a given product system that is measured in environmental impact categories. These input data cover the inputs from nature (resources), the inputs from the technosphere (materials and energy) and process characteristics (emissions to the air, water, soil, non-material emissions and waste flows) (Goedkoop et al. 2014). This is a quantitative analysis, because both the input data entered into the program and the results are given in numerical form (see figure 1).

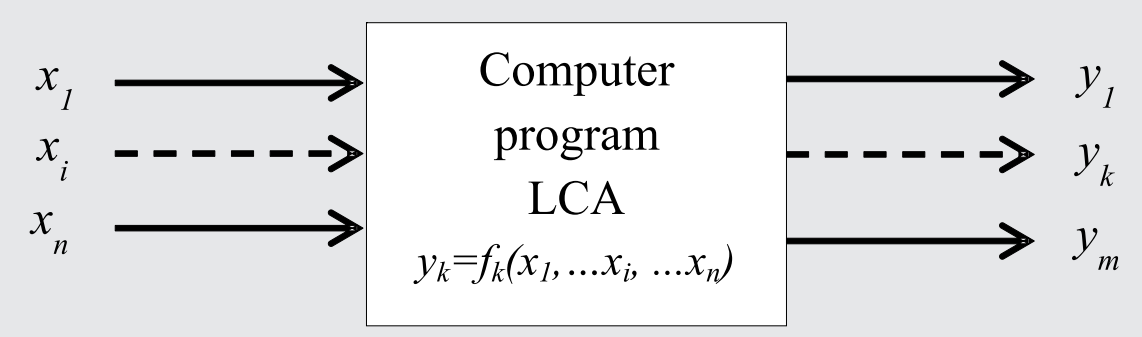

Figure 1. The scheme of life cycle assessment (LCAa) with the use of a specialized computer program: $x i=$ input signals; $i=1 \ldots n$ where $n=$ number of input signals; $y k$ - output; $k=1 \ldots m$ where $m=$ number of output signals

Source: own study

The dependencies between input and output signals are defined by nonlinear functions of several variables that can be presented as follows:

$$
y_{k}=f_{k}\left(x_{1}, \ldots x_{(\mathrm{i},)} \ldots x_{\mathrm{n}}\right)
$$


where:

$x_{i}=$ input signals (input data), e.g. materials, energy, emissions;

$i=1 \ldots n$, where $n=$ number of input signals;

$y_{k}=$ output signals (results of the analysis), in the form of impact categories; $k=1 \ldots m$, where $m=$ number of output signals.

The dependencies between input and output signals are created in a computer program according to special algorithms using e.g. material databases, various forms of energy generation or characteristics of production technologies. Basically, these algorithms are unknown to users of LCA programs. Solving the inverse problem is based on finding a method to determine the input signals that will provide the required (expected) values of the output signals. This, in general, means the determination of the dependencies in the form of inverse functions to function (1):

where:

$$
x_{i}=\varphi\left(y_{1}, \ldots y_{k^{\prime}}, \ldots y_{m}\right)
$$

$i=1 \ldots n$ and $n=$ number of output signals.

The completion of this task, i.e. the exact derivation of function (2), is not possible. The analytical form of function (1) is unknown. Moreover, these are non-linear functions of many variables, so the possibility of searching for inverse functions is limited. It is, though, possible to solve this problem in an approximate way by linearization of function (1) in the proximity of selected values (points). By determining the values of variables $x$, around which the linearization is performed as function (1) can be presented as follows:

where:

$$
y_{k}=y_{k}^{0}+a_{k 1} \Delta x_{1}+\cdots+a_{k i} \Delta x_{i}+\cdots+a_{k n} \Delta x_{n}
$$

$k=1 \ldots . . m$,

or using another form of notation:

$$
y_{k}=y_{k}^{0}+\sum_{i=1}^{n} a_{k i} \Delta x_{i}
$$

where:

$$
y_{k}^{0}=f_{k}\left(x_{i}^{0}\right), \Delta x_{i}=x_{i}-x_{i}^{0}, \quad \text { for } i=1 \ldots n
$$


By determining:

$$
\Delta y_{k}=y_{k}-y_{k}^{0} \text { for } k=1 \ldots m
$$

dependence (4) can be written as a system of linear equations:

$$
\Delta y_{k}=\sum_{i=1}^{n} a_{k i} \Delta x_{i}
$$

The next task is to determine the values of coefficient $a_{k i}$. To do this, $n$ linearly independent calculations have to be performed, where the value of one input signal is experimentally modified.

For each $\mu=1 \ldots n, \quad k=1 \ldots m$

$$
\begin{gathered}
y_{k \mu}^{*}=f_{k}\left(x_{i}^{0}+\Delta x_{\mu}^{*}\right) \quad i=1 \ldots n \\
\Delta x_{i}^{*}=0 \quad \text { for } \quad i \neq \mu
\end{gathered}
$$

By determining:

$$
\begin{aligned}
& \Delta y_{k i}^{*}=y_{k i}^{*}-y_{k}^{0} \\
& \Delta y_{k i}^{*}=a_{k i} \Delta x_{k i}^{*} \\
& a_{k i}=\frac{\Delta y_{k i}^{*}}{\Delta x_{k i}^{*}}
\end{aligned}
$$

Depending upon the number of input and output signals, the method of inverse problem calculation differs.

If $n=m$, then the system of linear equations (7) can be written in a matrix form:

$$
\Delta Y=A \cdot \Delta X
$$

where the individual matrices have the following form:

$$
\Delta Y=\left[\begin{array}{c}
\Delta y_{1} \\
\ldots \\
\Delta y_{k} \\
\ldots \\
\Delta y_{m}
\end{array}\right], \quad A=\left[\begin{array}{ccccc}
a_{11} & \ldots & a_{1 i} & \ldots & a_{1 n} \\
\ldots & \ldots & \ldots & \ldots & \ldots \\
a_{k 1} & \ldots & a_{k i} & \ldots & a_{k n} \\
\ldots & \ldots & \ldots & \ldots & \ldots \\
a_{m 1} & \ldots & a_{m i} & \ldots & a_{m n}
\end{array}\right], \quad \Delta X=\left[\begin{array}{c}
\Delta x_{1} \\
\ldots \\
\Delta x_{k} \\
\ldots \\
\Delta x_{m}
\end{array}\right], n=m
$$


The inverse problem can be solved from equation (13).

$$
\Delta X=A^{-1} \cdot \Delta Y
$$

Finally, according to dependence (5), input signals (input data) are as follows:

$$
x_{i}=x_{i}^{0}+\Delta x_{i} \text { for } i=1 \ldots n
$$

or in the matrix form:

$$
X=X^{0}+\Delta X
$$

where the individual matrices have the following form:

$$
X=\left[\begin{array}{c}
x_{1} \\
\ldots \\
x_{i} \\
\ldots \\
x_{n}
\end{array}\right], \quad X^{0}=\left[\begin{array}{c}
x_{1}^{0} \\
\ldots \\
x_{i}^{0} \\
\ldots \\
x_{n}^{0}
\end{array}\right], \quad \Delta X=\left[\begin{array}{c}
\Delta x_{1} \\
\ldots \\
\Delta x_{k} \\
\ldots \\
\Delta x_{m}
\end{array}\right]
$$

If $n>m$, then there are infinitely many solutions of the inverse problem. To select a single solution, it is necessary to determine additional conditions in number $\gamma=n-m$. These conditions can be introduced by identifying the relationships between inputs in the form of the following function:

for $s=\gamma+1, \ldots n$

$$
\Delta x_{s}=\vartheta\left(\Delta x_{1}, \ldots \Delta x_{\gamma}\right)
$$

As a result, the number of independent input signals $n$ is equal to the number of output signals $m$, and the inverse problem is solved analogously to (15).

If $n<m$, then there is no exact solution of the inverse problem. It is, though, possible to achieve an estimate being a result of minimization of a functional. By formulating the following functional

$$
\delta=\left(\Delta y_{1}-\sum_{i=1}^{n} a_{1 i} \Delta x_{i}\right)^{2}+\cdots+\left(\Delta y_{k}-\sum_{i=1}^{n} a_{k i} \Delta x_{i}\right)^{2}+\cdots+\left(\Delta y_{m}-\sum_{i=1}^{n} a_{m i} \Delta x_{i}\right)^{2}
$$

or using another form of notation:

$$
\delta=\sum_{k=1}^{m}\left(\Delta y_{k}-\sum_{i=1}^{n} a_{k i} \Delta x_{i}\right)^{2}
$$

the searched values $\Delta x_{i}$ for $i=1 \ldots n$ are determined by the condition of minimization: 


$$
\delta \rightarrow \delta_{\min }
$$

In practice, considering the nature of LCA analysis, there is either an equal number of input and output signals or a higher number of input than of output signals. The choice of input signals for the calculation of the inverse problem of LCA depends upon the goal and scope of the LCA analysis. Lowering the number of input signals taken into account, simplifies the calculations. The situation of $n=m$ is the subject of the current article, whereas the remaining two will be discussed in separate papers.

\section{Results and discussion}

The inverse problem of LCA is presented here as a case study of a coffee machine model SimaPro. The abstract model of coffee machine SimaPro is based on the sample models Sima and Pro, described in SimaPro version 8.1 software. It is a simplified example intended to show the applicability of the calculation of the inverse problem of LCA for DfE. Consequently, water and coffee consumption were not included in the analysis, since the coffee machine designers cannot influence them.

The life cycle of the coffee machine SimaPro covers the following product stages: assembly, use phase and disassembly. Based on the sample analysis of Sima and Pro, which the SimaPro software is equipped with, the material selection for the housing, energy efficiency and waste management scenarios were defined. The housing of the coffee machine is mainly made of aluminium with some plastic (polypropylene) elements. The electricity use, paper for coffee filter consumption and the packaging during the use phase were considered. A mix of various waste treatment processes, such as recycling, incineration and disposal, was adopted in the final waste management stage. The relative environmental contribution of different processes in the life cycle of the coffee machine SimaPro according to the ReCiPe Endpoint (H) method (Goedkoop et al. 2013), is presented in a graphic form as the process network (see figure 2). It shows that most of the environmental load is generated during the assembly and use phases of the coffee machine. The process contribution analysis proves that an aluminium housing, electricity consumption during the use phase and paper consumption for coffee filters are the most detrimental for the environment, as they are responsible for $85.9 \%(4.54 \mathrm{Pt})$ of negative environmental impacts being produced by the coffee machine SimaPro. 
According to the results of life cycle impact assessment (LCIA) of the coffee machine, based on the ReCiPe Endpoint $(\mathrm{H})$ method, the assembly phase and thus the use of aluminium has the greatest contribution to the succeeding impact categories: metal depletion (73\%) and freshwater eutrophication (58\%). At the same time, electricity consumption has the greatest share in the ionizing radiation category (64\%). Finally, the paper consumption for coffee filters contributes the most strongly to three impact categories: agricultural land occupation (97\%), urban land occupation (72\%) and natural land transformation (57\%) (see figure 3).

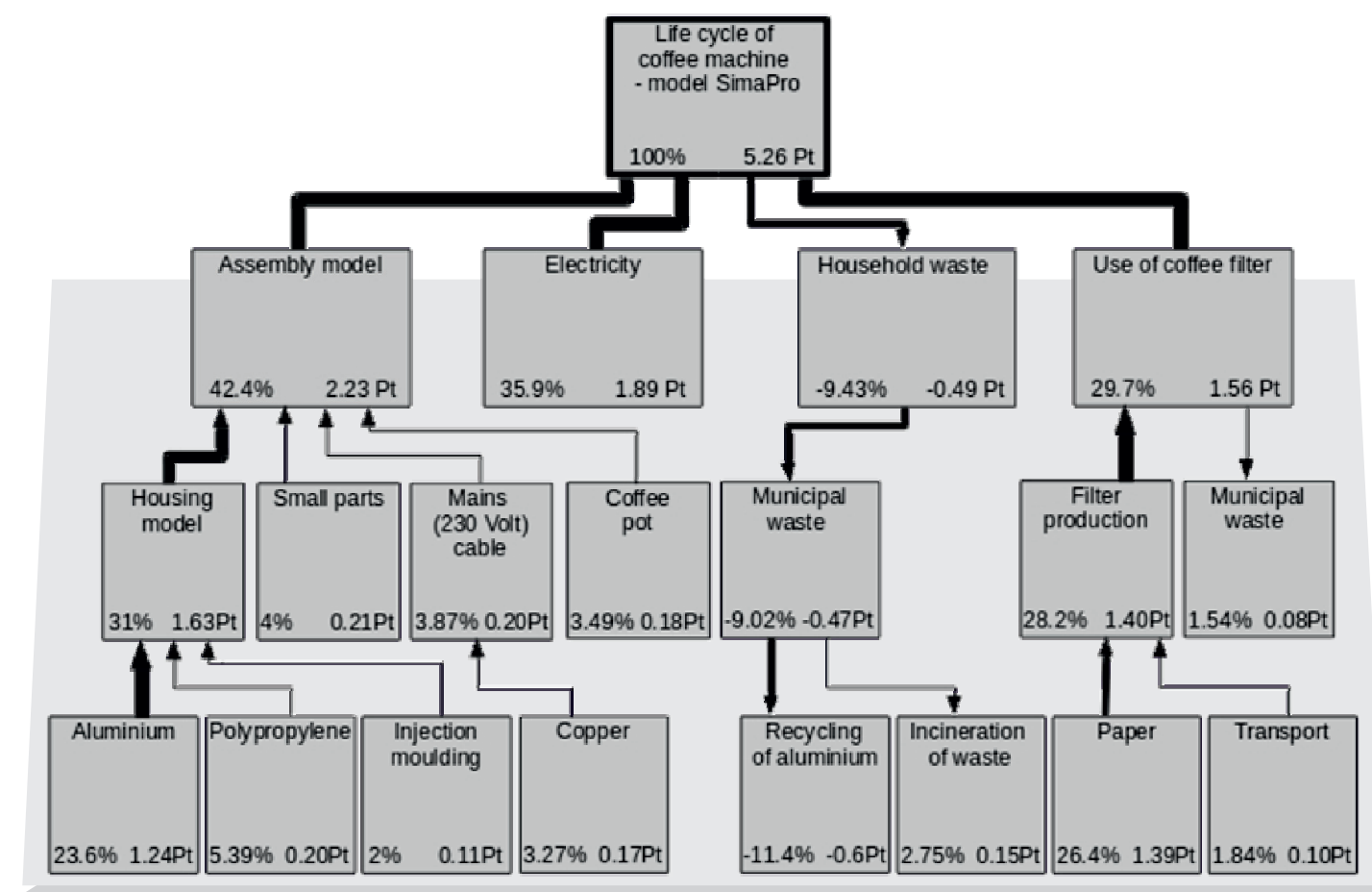

Figure 2. Process network for the coffee machine model SimaPro

Source: own study

Environmental impacts of the coffee machine SimaPro were also calculated in the endpoint impact categories, which in the ReCiPe Endpoint $(\mathrm{H})$ method are: human health, ecosystems and resources. Depending upon the category, the environmental load of the life cycle of the analysed coffee machine ranges from $0.35 \mathrm{Pt}$ in terms of ecosystems, $2.15 \mathrm{Pt}$ in terms of resources, up to $2.76 \mathrm{Pt}$ in terms 
of human health (see figure 4). Notwithstanding the endpoint impact category, the aluminium material, electricity consumption and use of paper for coffee filters have some contributions.

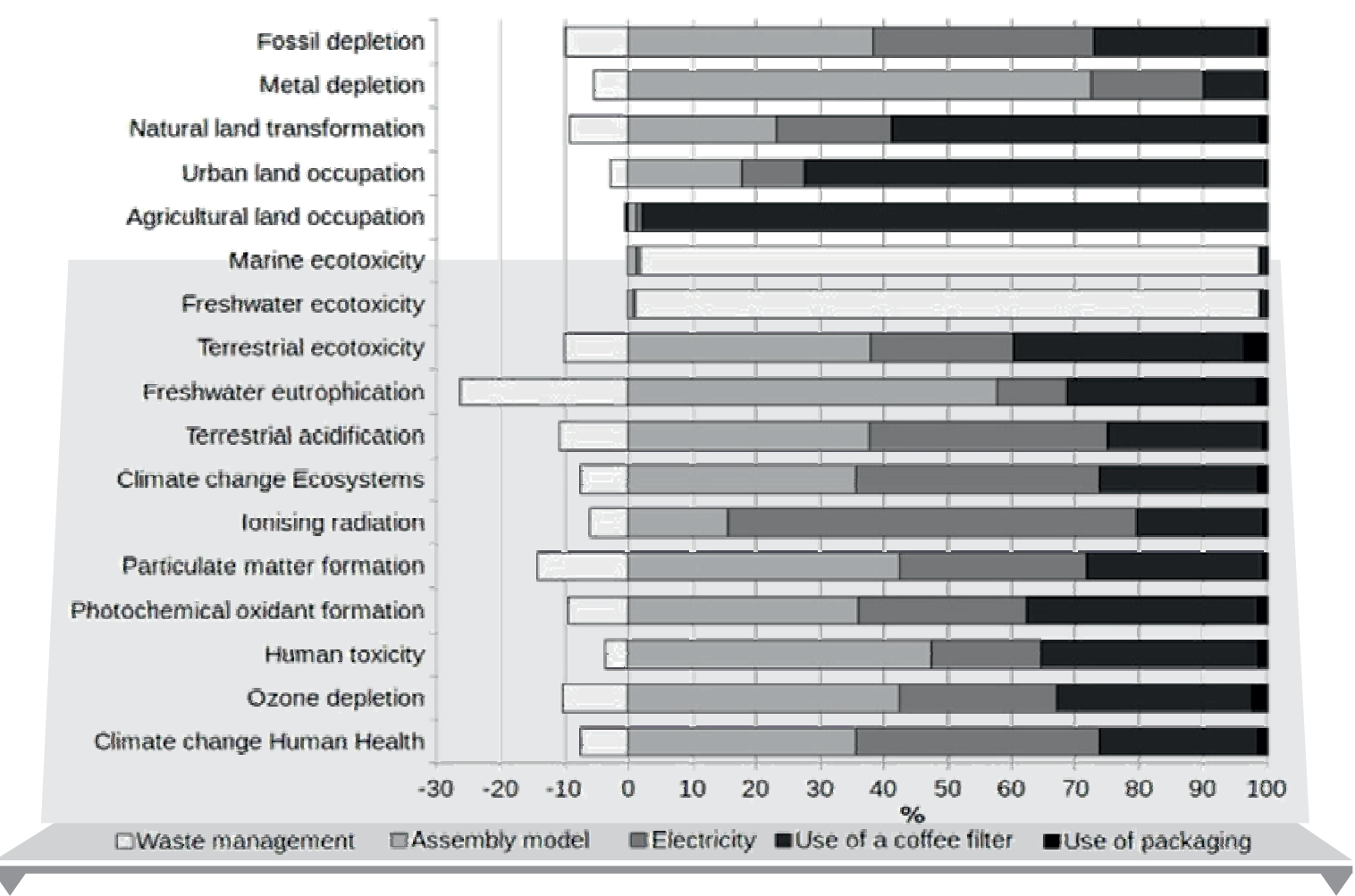

Figure 3. Life cycle impact assessment of the coffee machine model SimaPro in the midpoint impact categories

Source: own study

Following the DfE principles, input signals that are the most detrimental to the environment were selected to calculate the inverse problem of LCA. LCA analysis of the coffee machine SimaPro proved that these were: the material for housing (aluminium) (1.5kg), the energy consumed during the use of the coffee machine $(0.13 \mathrm{GJ})$ and finally the amount of paper consumed for coffee filter production $(0.002 \mathrm{~kg})$. Consequently, the set of input signals was as follows:

- $x_{1}=$ consumption of aluminium $[\mathrm{kg}]$,

- $x_{2}=$ consumption of electricity [GJ],

- $x_{3}=$ consumption of paper for coffee filters [kg]. 


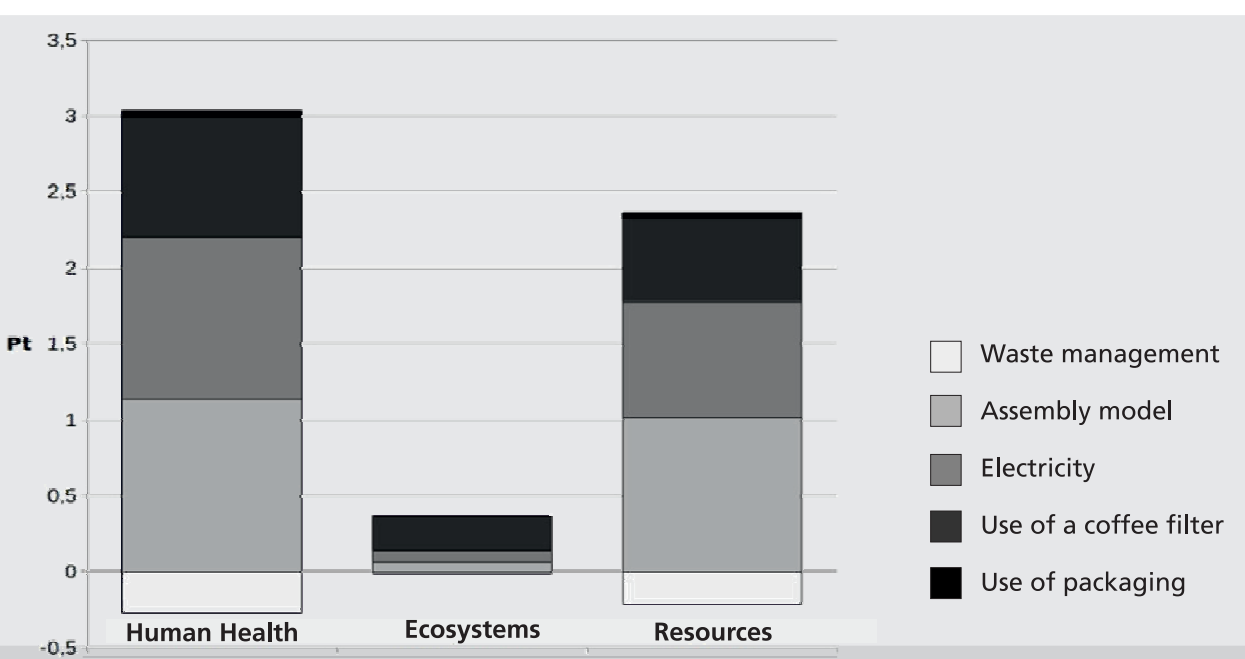

Figure 4. Life cycle impact assessment of the coffee machine model SimaPro in the endpoint impact categories

Source: own study

On the other hand, the set of output signals - results of the LCA analysis, expressed in the endpoint impact categories - was as follows:

- $y_{1}=$ human health $[\mathrm{Pt}]$,

- $y_{2}=$ ecosystems [Pt],

- $y_{3}=$ resources $[\mathrm{Pt}]$.

Having regard to the above, the number of input signals $n$ is equal to the number of output signals $m$,-and thus, in order to solve the inverse problem of LCA, the determination of additional conditions is not required. It is sufficient to conduct three numerical experiments for the selected input signals, where the values of these signals will be sequentially reduced by e.g. $10 \%$. To calculate the values of coefficients $a_{k i}$ of matrix $A$, the relative changes in the initial values of input and output signals are applied.

Experiment 1. Reduction of the consumption of aluminium by $10 \%\left(\Delta x_{1}=\right.$ $-0.15 \mathrm{~kg})$.

If, for example, $x_{11}=1.35 \mathrm{~kg}, x_{12}=0.13 \mathrm{GJ}$ and $x_{13}=0.002 \mathrm{~kg}$, then $y_{11}=2.72 \mathrm{Pt}, y_{12}=$ $0.352 \mathrm{Pt}$ and $y_{13}=2.12 \mathrm{Pt}$, and hence $\Delta y_{11}=0.04 \mathrm{Pt}, \Delta y_{12}=0.003 \mathrm{Pt}$ and $\Delta y_{13}=0.03 \mathrm{Pt}$. As a result, based on (12), the values of coefficients $a_{k i}$ are as follows:

$$
a_{11}=\frac{\Delta y_{11}^{*}}{\Delta x_{1}^{*}}=0.144927536
$$




$$
\begin{aligned}
& \qquad \begin{array}{l}
\text { Management } \\
2016 \\
\text { Vol. 20, No. 2 }
\end{array} \\
& a_{21}=\frac{\Delta y_{12}^{*}}{\Delta x_{1}^{*}}=0.084507042 \\
& a_{31}=\frac{\Delta y_{13}^{*}}{\Delta x_{1}^{*}}=0.139534884
\end{aligned}
$$

Experiment 2. Reduction of the consumption of electricity by $10 \%\left(\Delta x_{2}=-0.013 \mathrm{GJ}\right)$. If, for example, $x_{21}=1.5 \mathrm{~kg}, x_{22}=0.117 \mathrm{GJ}$ and $x_{23}=0.002 \mathrm{~kg}$, then $y_{21}=2.65 \mathrm{Pt}, y_{22}=$ $0.347 \mathrm{Pt}$ and $y_{23}=2.07 \mathrm{Pt}$, and hence $\Delta y_{21}=0.11 \mathrm{Pt}, \Delta y_{22}=0.008 \mathrm{Pt}$ and $\Delta y_{23}=0.08 \mathrm{Pt}$. As a result, the values of coefficients $a_{k i}$ are as follows:

$$
\begin{aligned}
& a_{12}=\frac{\Delta y_{21}^{*}}{\Delta x_{2}^{*}}=0.398550725 \\
& a_{22}=\frac{\Delta y_{22}^{*}}{\Delta x_{2}^{*}}=0.225352113 \\
& a_{32}=\frac{\Delta y_{23}^{*}}{\Delta x_{2}^{*}}=0.372093023
\end{aligned}
$$

Experiment 3. Reduction of the consumption of paper for coffee filters by $10 \%$ $\left(\Delta x_{3}=-0.0002 \mathrm{~kg}\right)$.

If, for example, $x_{31}=1.5 \mathrm{~kg}, x_{32}=0.13 \mathrm{GJ}$ and $x_{33}=0.0018 \mathrm{~kg}$, then $y_{31}=2.68 \mathrm{Pt}, y_{32}=$ $0.333 \mathrm{Pt}$ and $y_{33}=2.09 \mathrm{Pt}$, and hence $\Delta y_{31}=0.08 \mathrm{Pt}, \Delta y_{32}=0.022 \mathrm{Pt}$ and $\Delta y_{33}=0.06 \mathrm{Pt}$. As a result, the values of coefficients $a_{k i}$ are as follows:

$$
\begin{aligned}
& a_{13}=\frac{\Delta y_{31}^{*}}{\Delta x_{3}^{*}}=0.289855072 \\
& a_{23}=\frac{\Delta y_{32}^{*}}{\Delta x_{3}^{*}}=0.619718310 \\
& a_{33}=\frac{\Delta y_{33}^{*}}{\Delta x_{3}^{*}}=0.279069767
\end{aligned}
$$

The calculated values of coefficients $a_{k i}$ show how the changes of $x_{1}-x_{3}$ input signals affect the changes of $y_{1}-y_{3}$ output signals.

As the number of input signals is equal to the number of output signals, it is possible to define the following matrices:

$$
A=\left[\begin{array}{lll}
0.144927536 & 0.398550725 & 0.289855072 \\
0.084507042 & 0.225352113 & 0.619718310 \\
0.139534884 & 0.372093023 & 0.279069767
\end{array}\right]
$$




$$
\begin{array}{r}
\begin{array}{r}
\text { Management } \\
2016 \\
\text { Vol. 20, No. 2 }
\end{array} \\
\Delta Y=\left[\begin{array}{rrr}
-0.0144 & -0.0398 & -0.0289 \\
-0.0084 & -0.0225 & -0.0619 \\
-0.0139 & -0.0372 & -0.0279
\end{array}\right]
\end{array}
$$

$$
\Delta X=\left[\begin{array}{c}
-0.1 \\
-0.1 \\
-0.1
\end{array}\right]
$$

In accordance with (15), the inverse matrix $\mathrm{A}^{-1}$ is calculated as follows:

$$
\mathrm{A}^{-1}=\left[\begin{array}{ccc}
-220.8 & -4.4372 & 239.1875 \\
82.8 & 9.53 \mathrm{E}-14 & -86 \\
3.04 \mathrm{E}-14 & 2.21875 & -1.34375
\end{array}\right]
$$

After conducting the above experiments, the combination of the input signals (most harmful to the environmental factors in the life cycle of the coffee machine model SimaPro) that provide the required values of the output signals will be calculated. Suppose that the manufacturer of the coffee machine wants to decrease the environmental load in all endpoint impact categories, for example by $5 \%$, and thus to achieve their following values $y 1=2.62 \mathrm{Pt}, y 2=0.34 \mathrm{Pt}$ and $y 3$ $=2.04 \mathrm{Pt}$. According to the obtained results, in order to make the environmental impacts equal to the expected ones, the designer of the coffee machine needs to decrease the aluminium content of the housing of the coffee machine by approximately $1.04 \mathrm{~kg}$, consume about $0.00009 \mathrm{~kg}$ less paper from virgin pulp per coffee filter and increase the consumption of energy during the use phase of the coffee machine by $0.02 \mathrm{GJ}$. The allowable increase in energy consumption should not, however, be taken literally, but rather as a suggestion that the consumption of a larger amount of energy will not affect the results in the form of a lower environmental load. The results were verified in the SimaPro software and in both the category of human health and the category of ecosystems the values are identical, whereas in terms of resources it is equal to $2.08 \mathrm{Pt}$, so this value is slightly different from the calculated one (see figure 5).

In the analysed case study, the decrease in the consumption of aluminium and paper can bring numerous environmental benefits. The most significant benefits are: savings in energy consumption (e.g. for the production of $1 \mathrm{~kg}$ of aluminium, approximately $13 \mathrm{kWh}$ of energy is needed), savings in natural resources consumption (e.g. for the production of $1 \mathrm{~kg}$ of paper, approximately $2.2 \mathrm{~kg}$ of wood is required), and finally a reduced pollution emission, particularly 


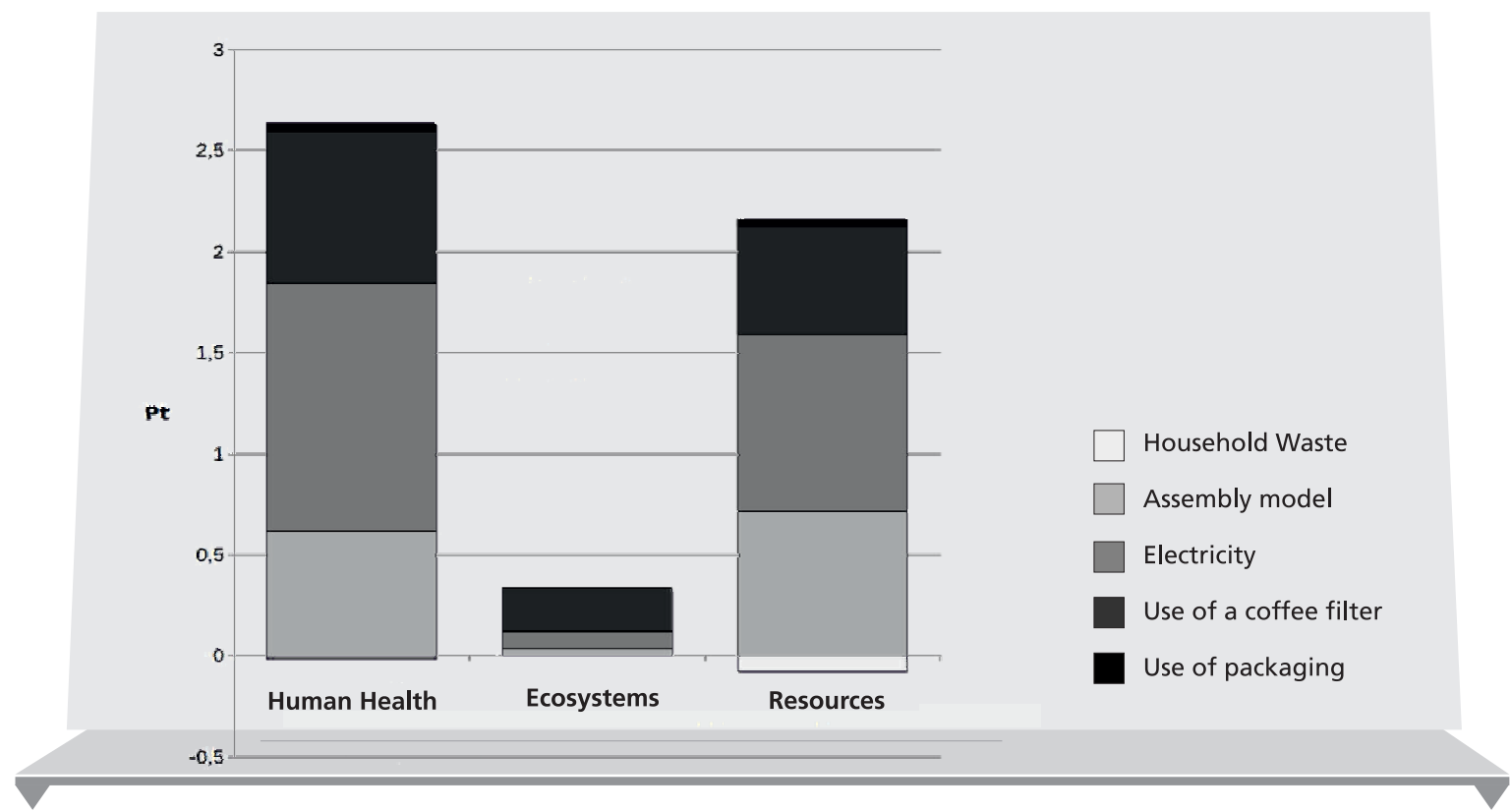

Figure 5. Life cycle impact assessment in designing for environment of the coffee machine model SimaPro in the endpoint impact categories

\section{Source: own study}

wastewater and air contamination, reflected in biological oxygen demand (BOD), chemical oxygen demand (COD), concentrations of phosphorus and nitrogen compounds and $\mathrm{CO}_{2}$ (Michniewicz 2005, pp. 50-57; Kvande, Drabløs 2014, pp. 25). Additionally, to decrease the environmental impacts, the producers of coffee machines ought to consider the replacement of primary raw materials with secondary raw materials. For instance, instead of virgin pulp, recycled waste paper can be used.

\section{Conclusions}

The integration of the inverse problem theory with the practice of LCA is not only a relatively new concept but also a very prospective one. Ultimately, it may become a professional tool for eco-design that allows a concurrent optimization of product design from the functional and environmental point of view, and thus brings a multi-criteria approach.

Following the DfE principles, the abstract model of coffee machineSimaPro was developed and subsequently thoroughly analysed. As a result, recommendations have been made on modification of the values of the factors that are the most 
detrimental for the environment: the consumption of aluminium, electricity, and paper for coffee filters. Although the presented results cannot be implemented in industrial practice literally, they indicate the areas for eco-innovation of coffee machines. At the same time, they illustrate the applicability and usefulness of the proposed approach.

The solution of the LCA inverse problem allows finding the optimal values of environmental inputs that provide the required environmental impacts without the necessity of reaching them by trial and error. The calculation results present the suggestions for changes concerning the materials and manufacture methods. It is a significant support for designers, as on these grounds they can choose the best variant for the construction of environmentally friendly products. It should be noted that the decrease in the consumption of material or changes in the production processes must not reduce the functionality of the products. Therefore, the application of the inverse problem of LCA in DfE requires further research. Consequently, a prospective research with regard to other products and thus different input and output signals is planned.

Solving the inverse problem of LCA requires suitable computer programs. On the specialized market of software for LCA analysis there is no program that would provide an option of inverse problem solution. Thus it is a prospective concept. The practical application of the LCA inverse problem also requires the combination of LCA and CAD software, so that it would be possible to transfer the data quickly from one program to another one. Only the inclusion of LCA analysis in the process of designing in CAD systems will allow the complete consideration of environmental aspects in the designing process of products.

\section{Summary}

Inverse problem of life cycle assessment (LCA): its application in designing for environment (DfE)

The inverse problem of life cycle assessment, used in designing for environment, is about determining the optimal values of environmental inputs that provide the required environmental impacts. The notion of the inverse problem of life cycle assessment is explained here using a case study of a coffee machine (abstract model SimaPro, based on models Sima and Pro described in SimaPro 8.1 software). The dependencies between input and output signals were defined by nonlinear functions of several variables. Next, linearization was used and coefficient $a_{k i}$ was calculated. On the basis of 3 hypothetical experiments, recommendations have been made 
on the reduction of the value of the factors that are the most detrimental for the environment: the consumption of aluminium, electricity, and paper for coffee filters, for the analysed product. The results prove the high applicability and usefulness of the proposed approach during environmental evaluation and enhancement of products over the full product life cycle.

Keywords: design for environment, DfE, inverse problem, life cycle assessment, LCA.

\section{Streszczenie}

\section{Zagadnienie odwrotne oceny cyklu życia (LCA): zastosowanie w projektowaniu dla środowiska (DfE)}

Zastosowanie $\mathrm{w}$ projektowaniu dla środowiska zagadnienia odwrotnego oceny cyklu życia pozwala ustalić optymalne wartości wejść środowiskowych, które zapewniają wymagane wpływy środowiskowe. $\mathrm{W}$ niniejszym artykule wyjaśniono pojęcie zagadnienia odwrotnego oceny cyklu życia na przykładzie ekspresu do kawy (abstrakcyjnego modelu SimaPro opartego na modelach Sima i Pro pochodzących z oprogramowania SimaPro 8.1). Stosując nieliniową funkcję wielu zmiennych określano zależności pomiędzy sygnałami wejściowymi i wyjściowymi. Następnie przeprowadzono linearyzację i obliczono współczynniki $a_{k i}$. Na podstawie 3 hipotetycznych eksperymentów zostały ustalone dla analizowanego wyrobu zalecenia pozwalające na zmniejszenie wartości czynników najbardziej szkodliwych dla środowiska tzn.: zużycia aluminium, energii elektrycznej oraz papieru wykorzystywanego do wytwarzania filtrów do kawy. Wyniki potwierdzają wysoką przydatność i użyteczność proponowanego podejścia w ocenie oddziaływania na środowisko i w poprawie wyrobów podczas całego ich cyklu życia.

\section{Słowa}

kluczowe: projektowanie dla środowiska, DfE, zagadnienie odwrotne, ocena cyklu $\dot{\mathbf{z} y c i a}, L C A$.

\section{References}

1. Andriankaja, H., Vallet, F., Le Duigou, J. and Eynard, B. (2015), A method to ecodesign structural parts in the transport sector based on product life cycle management, Journal of Cleaner Production, 94, 165-176. 
2. Argoul, P. (2012). Overview of Inverse Problems, Ecole Nationale des Ponts et Chaussées, 1-13.

3. Arnette, A., Brewer, B. and Choal, T. (2014), Design for sustainability (DFS): the intersection of supply chain and environment, Journal of Cleaner Production, 83, 374-390.

4. Birch, A., Hon, K.K.B. and Short, T. (2012), Structure and output mechanisms in Design for Environment (DfE) tools, Journal of Cleaner Production, 35, 50-58.

5. Bovea, M.D. and Perez-Belis, V. (2012), A taxonomy of ecodesign tools for integrating environmental requirements into the product design process, Journal of Cleaner Production, 20, 61-71.

6. Casamayor, J.L. and Su, D. (2012), Integration of eco-design tools into the development of eco-lighting products, Journal of Cleaner Production, 47, 32-42.

7. Chang. D., Lee, C.K.M. and Chen, Ch. (2014), Review of life cycle assessment towards sustainable product development, Journal of Cleaner Production, 83, 48-60.

8. Ecodesign Directive 2009. Directive 2009/125/EC of the European Parliament and of the Council of 21 October 2009 establishing a framework for the setting of ecodesign requirements for energy-related products.

9. Engl, H.W., Hanke, M. and Neubauer, A. (2000), Regularization of inverse problems, Dordrecht/Boston/London: Kluwer Academic Publishers.

10. Fargnoli, M. (2009), Design Process Optimization for EcoDesign, International Journal of Automation Technology, 3 (1), 33-39.

11. Fiksel, J. and Wapman, K. (1994, May). How to design for environment and minimize life cycle costs, Paper presented at the IEEE International Symposium on Electronics and the Environment, San Francisco.

12. Goedkoop, M., Heijungs, R., Huijbregts, M., Schryver, A.D., Struijs, J. and van Zelm, R. (2013), ReCiPe 2008. A life cycle impact assessment method which comprises harmonised category indicators at the midpoind and the endpoint level, PRé, CLM, RUN, RIVM, 2013, https://www.pre-sustainability. com/download/ReCiPe_main_report_MAY_2013.pdf (21.10.2016 - access date).

13. Goedkoop, M., Oele, M., Vieira, M., Leijting, J., Ponsioen, T. and Meijer, E. (2014), SimaPro Tutorial. PRé 2014, http://www.pre-sustainability.com/ simapro-tutorial (8.05.2016 - access date).

14. Hensel, E. (1991), Inverse Theory and Applications for Engineers, New Jersey: Prentice Hall.

15. Herva, M., Franco-Uria, A., Carrasco, E.F. and Roca, E. (2012), Application of fuzzy logic for the integration of environmental criteria in eco-design, Expert Systems with Applications, 39, 4427-4431.

16. Horne, R., Grant, T. and Verghese, K. (2009), Life Cycle Assessment: Principles, Practice and Prospects, Collingwood Australia: CSIRO Publishing.

17. ISO, 2006a. International Standard ISO 14040. Environmental management - Life cycle assessment - Principles and framework. 
18. ISO, 2006b. International Standard ISO 14044. Environmental management - Life cycle assessment - Requirements and guidelines.

19. Kaczmarska, B. and Gierulski, W. (2014), Designing Innovative Products in Terms of LCA. Structure and Environment, Architecture, Civil Engineering, Environmental and Energy, 6 (2), 48-55.

20. Karlsson, R. and Luttropp, C. (2006), EcoDesign: what's happening? An overview of the subject area of ecodesign and of the papers in this special issue', Journal of Cleaner Production. 14, 1291-1298.

21. Kunze, H.E., La Torre, D., Mendivil, F., Ruiz Galan, M. and Zaki, R. (2014), Inverse Problems: Theory and Application to Science and Engineering, Mathematical Problems in Engineering, 2014.

22. Kvande, H. and Drabløs, P.A. (2014), The Aluminium Smelting Process and Innovative Alternative Technologies, Journal of Occupational and Environmental Medicine, 56 (5S), 23-32.

23. Luza, S.M, Caldeira-Pires, A. and Ferrao, P. (2010), Environmental benefits of substituting talc by sugarcane bagasse fibers as reinforcement in polypropylene composites: Ecodesign and LCA as strategy for automotive components, Resources, Conservation and Recycling, 54, 1135-1144.

24. Masternak-Janus, A. and Rybaczewska-Błażejowska, M. (2015), Life cycle analysis of tissue paper manufacturing from virgin pulp or recycled waste paper, Management and Production Engineering Review, 6 (3), 47-54.

25. Michniewicz, M. (2005), Najlepsze dostępne techniki (BAT). Wytyczne dla branży celulozowo-papierniczej [The Best Available Techniques (BAT). Guidelines for the Pulp and Paper Industry], Ministry of the Environment.

26. Millet, D., Bistagnino, L., Lanzavecchia, C., Camous, R. and Poldma, T. (2007), Does the potential of the use of LCA match the design team needs?, Journal of Cleaner Production, 4, 335-346.

27. Telenko, C., Seepersad, C. and Webber, M. (2008, August), A compilation of design for environment principles and guidelines, Paper presented at the ASME 2008 International Design Engineering Technical Conferences \& Computers and Information in Engineering Conference; American Society of Mechanical Engineers, New York, 1-13.

28. Tukker, A. (2002), Handbook on Life Cycle Assessment, New York, Boston, Dordrecht, London, Moscow: Kluwer Academic Publishers.

29. Wang, Y., Yagola, A.G. and Yang, C. (2012), Computational Methods for Applied Inverse Problems, Inverse and Ill-Posed Problems Series 56. Berlin/ Boston: Higher Education Press and Walter de Gruyter GmbH.

30. Van der Velden, N.M., Kuusk, K. and Köhler, A.R. (2015), Life cycle assessment and eco-design of smart textiles: The importance of material selection demonstrated through e-textile product redesign, Materials and Design, 84, 313-324.

31. Zufia, J. and Arana, L. (2008), Life cycle assessment to eco-design food products: industrial cooked dish case study, Journal of Cleaner Production, 16, 1915-1921. 